\begin{tabular}{l}
$\begin{array}{c}\text { Yanbu Journal } \\
\text { of } \\
\text { Engineering } \\
\text { and Science }\end{array}$ \\
\hline \hline ISSN: $1658-5321$ \\
Vol. 15, December $2017(1438 \mathrm{H})$ \\
www.yjes.org.sa
\end{tabular}

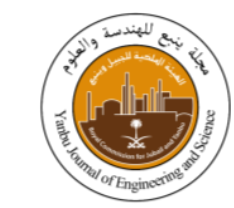

\title{
OPTIMAL PLACEMENT OF D-STATCOM USING QUADRATIC ADAPTIVE BACTERIAL FORAGING ALGORITHM
}

\author{
Umar Musa ${ }^{1,}$, Ganiyu A. Bakare ${ }^{2}$, Abdullahi A. Mati ${ }^{1,3}$, Abdullahi Abubakar Mas'ud ${ }^{4}$ \\ ${ }^{1}$ Department of Electrical and Computer Engineering, Ahmadu Bello University, Zaria, Nigeria \\ ${ }^{2}$ Department of Electrical and Electronics Engineering, Abubakar Tafawa Balewa University, Bauchi, Nigeria \\ ${ }^{3}$ Center for Energy Research and Training (CERT), Ahmadu Bello University, Zaria, Nigeria \\ ${ }^{4}$ Department of Electrical and Electronic Engineering, Jubail Industrial College, Jubail Industrial City, Saudi Arabia \\ E-mail: umarnadada@yahoo.co.uk
}

\begin{abstract}
Optimal placement of Distribution Flexible AC Transmission Systems (D-FACTS) devices in power networks maximizes loadability, compensates reactive power, minimizes power loss and enhances voltage profile. In this paper, a Quadratic Adaptive Bacterial Foraging Algorithm (QABFA) is used to the optimal location and sizing of Distribution Static Compensator (D-STATCOM) in radial distribution networks for loss minimization and voltage profile enhancement. Power losses and voltage deviation are calculated using a direct power flow method. A multi-objective function made-up of total active power loss $\left(\mathrm{P}_{\mathrm{T}(\text { loss })}\right)$ and bus voltage deviation $\left(\mathrm{V}_{\mathrm{D}}\right)$ is formulated. The QABFA is modelled with a quadratic run-length unit, and without the cell-to-cell signalling mechanism. The effectiveness of the proposed method is investigated on the IEEE 33bus standard network. The proposed QABFA approach produced a $28.96 \%$ reduction in total active power loss and $43.11 \%$ improvement in the overall network voltage profile as compared to the base-case scenario. Similarly, in comparison to the bat algorithm (BA) approach, the QABFA results confirmed a slight reduction $(0.83 \%)$ in active power loss and $11.95 \%$ improvement in voltage profile.
\end{abstract}

Keywords: Distribution Flexible AC Transmission Systems, Distribution Static Compensator, Bacterial Foraging Algorithm.

\section{INTRODUCTION}

Technically, electric power systems are considered as large networks due to their spatially extended nature and large number of structural components [1]. These networks comprises of three major interconnected components, namely, generation, transmission network and distribution network [2]. Recent studies showed that $10-13 \%$ of the total generation is dissipated as $\mathrm{I}^{2} \mathrm{R}$ losses at the distribution level [3]. However, due to presence of reactance, most AC loads also consume reactive power, which often results in poor power quality. In the past, several techniques such as load reduction and load shedding have been employed in mitigating such problems. The advent of Distribution Flexible AC Transmission System (DFACTS) devices has paved way for a more robust and effective approach of improving the network quality [4]. Custom power devices, such as DSTATCOM, UPQC, DVR are now widely used for improving 
power quality and reliability of supply to sensitive loads in power distribution networks. The excellent features of DSTATCOM that includes less harmonic distortion, low power losses, zero resonance, compact size, low cost and high regulatory capability makes it superior over other DFACTS devices [5]. The major challenge in deploying these devices involves determining their optimal location and size for a given distribution network. Thus, despite the use of several techniques, identifying the best size and location of these devices within the network remains a serious concern to researchers. The application of harmony search algorithm for placement of D-STATCOM in radial distribution systems was reported in [6]. In Shanmugasundaram et al., analytically based approach for obtaining the best location and size of $\mathrm{D}$ STATCOM in distribution networks was presented [7]. An effective cuckoo search algorithm has been proposed for the best capacitor banks placement [8]. A Modified Bacterial Foraging Optimization (MBFO) algorithm approach was employed in $[9,10]$ for DG placement in radial distribution systems. Recently, several approached such as Imperialist Competitive Algorithm [11], Deferential Evolution Algorithm [12], phase angle injection model $[13,14]$ and Fuzzy-GA [15] have all been used for allocating D-STATCOM in radial distribution networks with the sole intent of improving system stability. In this paper, a quadratic adaptive bacterial foraging algorithm (QABFA) is investigated for determining the optimal position and size of D-STATCOM in radial distribution networks in order to enhance the voltage profile and reduce losses.

\section{DISTRIBUTION STATIC COMPENSATOR}

\subsection{BRIEF OVERVIEW OF THE D-STATCOM}

According to IEEE, "D-STATCOM is defined as a static synchronous generator operating as a Static Var Compensator (SVC) connected in parallel at a point of common coupling at the bus, and the output current can be controlled independently of the AC voltage network" [16]. A typical model of D-STATCOM as shown in Figure 1 comprises a DC capacitor, a GTO/IGBT, a coupling transformer and a voltage source converter (VSC) [17].

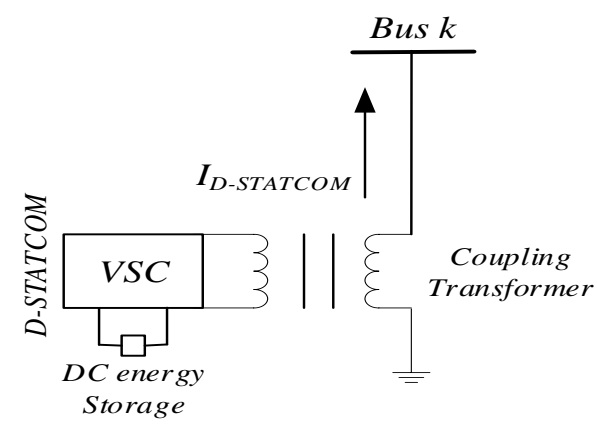

Fig.1. Structure of D-STATCOM Connected to Bus $k$ [17].

\subsection{OPerating Principle OF D-STATCOM}

Similar to the synchronous machine, the DSTATCOM provides lagging current when under excited and leading current when over excited. The voltage of D-STATCOM is injected in phase with the line voltage. Under this condition, there is no exchange of energy with the network, but rather the injection (or absorption) of reactive power into the network by the D-STATCOM as depicted in Figure 2 [17].

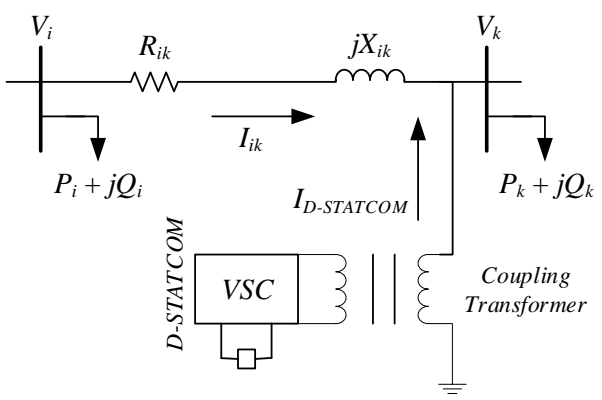

Fig.2. Line diagram of two buses with D-STATCOM incorporated [17]. 


\subsection{MATHEMATICAL MODEL OF D-STATCOM}

Based on Figure 2, the active and reactive power exchanged with the network at bus $k$ is modelled as [16]:

$P_{D-S T A T C O M}=\frac{V_{k} V_{D-S T A T C O M}}{X_{k, D-S T A T C O M}} \sin \left(\delta_{k}-\delta_{D-S T A T C O M}\right)$

$Q_{D-S T A T C O M}=-\frac{V_{k}\left\{V_{D-S T A T C O M} \operatorname{Cos}\left(\delta_{k}-\delta_{D-S T A T C O M}\right)-V_{k}\right\}}{X_{k, D-S T A T C O M}}$

with $V_{k}, V_{D}$-STATCOM, $X_{k}, D-S T A T C O M$, $\delta_{k}$ and $\delta_{D}$-STATCOM as the absolute voltage at bus $k$, absolute voltage of $\mathrm{D}$ STATCOM, line reactance, voltage phase angle at bus $k$ and voltage phase angle of $\mathrm{D}$ STATCOM respectively. Assume $P_{D^{-}}$ $S T A T C O M$ and $Q_{D}-S T A T C O M$ to be constant and the values of $V_{k}$ and $\delta_{k}$ are known, then the values of $V_{D}-S T A T C O M$ and $\delta_{D}-S T A T C O M$ can be computed.

\section{PROBLEM FORMULATION}

The essence of introducing D-STATCOM into the power network at the distribution level is to find a set of optimal trade-off between voltage and losses.

\subsection{POWER Flow ANALysis}

Classical power flow techniques, in most cases, fail to converge at the distribution level. An elaborate power flow approach for radial distribution network has been adopted from [13].

\subsection{OBJECTIVE FUNCTION}

Here, the aim is to minimize total active power loss $P_{T(\text { loss })}$ and voltage deviation $V_{D}$ giving by [18]:

$$
\begin{aligned}
& P_{T(\text { loss })}=\sum_{i k=1}^{N_{\text {Branch }}}\left|I_{B(i k)}\right|^{2} * \Re\left(Z_{i k}\right) \\
& V_{D}=\sum_{k=1}^{N_{B u s}}\left(V_{k}-V_{k}^{\text {ref }}\right)^{2}
\end{aligned}
$$

for $i k=1,2,3, \ldots, N_{\text {Branch }}$

"where $N_{\text {Branch }}$ and $N_{\text {Bus }}$ are number of branches and buses respectively". $\mathfrak{R}$ denotes real component, while $v_{k}$ and $v_{k}^{r e f}$ are the per-unit (p.u) voltage values at bus $k$ and the reference bus respectively. Then, the objective function $(/)$ is formulated using the sum of equations (3) and (4) to give:

$$
\min (J)=\min \left(\mu P_{T(\text { loss })}+\psi V_{D}\right)
$$

where $\mu$ and $\psi$ are the weighting metrics for active power loss and voltage deviation respectively. The objectives in equation (5) are considered to be of equal importance in this work. Thus, a unit weighting metric is attached to both objectives $(\mu=\psi=1)$. The network constraints are explained by the power flow equations expressed as:

$$
\begin{aligned}
& \sum_{k=1}^{N_{B u s}} P_{G k}-P_{D k}=P_{L} \\
& \sum_{k=1}^{N_{B u s}} Q_{G k}-Q_{D k}=Q_{L}
\end{aligned}
$$

where:

$P_{G k}$ and $Q_{G k}$ represent total real and reactive power generation at bus $k$ respectively, $P_{D k}$ and $Q_{D k}$ represent the total real and reactive power demand at bus $k$ respectively. $P_{L}$ and $Q_{L}$ represent the total active and reactive power losses. The inequality constraints represent the network load bus and DSTATCOM size limits given by:

$$
\begin{aligned}
& \lambda_{n}^{\min } \leq \lambda_{n} \leq \lambda_{n}^{\max } \\
& Q_{n}^{\min } \leq Q_{n} \leq Q_{n}^{\max }
\end{aligned}
$$

\section{BASIC CONCEPTS}

\subsection{BACTERIAL FORAGING ALGORITHM (BFA)}

The BFA is a member of the swarm based nature inspired algorithm developed based on four principal behaviours of Escherichia Coli (E. Coli) bacteria $[19,20]$.

a. Chemotaxis: Chemotaxis explains the procedure in which the bacteria conducts their movements over a 
landscape of nutrients. The $i$ th bacterium movement is performed by:

$\theta^{i}(j+1, k, l)=\theta^{i}(j, k, l)+C(i) \phi(i)$

where $\theta^{i}(j, i, k)$ is the position of $i$ th bacterium at $j$ th chemotactic, $k$ th is the reproductive, $l$ th is the dispersion and elimination step. Also, $C(i)$ is the run-length unit and $\phi(i)$ represent the $j$ th step direction angle. The fitness of the $i$ th bacterium is determined based on its position represented by $J=J(i, j, k, l)$. The direction angle $\phi(i)$ describes the tumble of the bacteria as:

$$
\phi(i)=\frac{\Delta(i)}{\sqrt{\Delta^{T}(i) \Delta(i)}}
$$

where $\Delta(i) \in \mathrm{R}^{P} \quad$ represents the randomly generated vector.

b. Swarming: The attractive and repulsive effects of each bacterium are used as a medium of communication to others. Attractants are released by bacteria under stress circumstances to indicate bacteria to swarm together, while repellent are released to inform others to maintain a reasonable interval from the stressed bacterium. The bacteria cell-to-cell signalling mechanism is represented as follows: $J_{c c}=(\theta, P(j, k, l))$

$$
\begin{aligned}
& =\sum_{i=1}^{S}\left[-d_{\text {atract }} \exp \left(-\omega_{\text {atract }} \sum_{m=1}^{p}\left(\theta_{m}-\theta_{m}^{i}\right)^{2}\right)\right] \\
& +\sum_{i=1}^{S}\left[h_{\text {repellant }} \exp \left(-\omega_{\text {repellant }} \sum_{m=1}^{p}\left(\theta_{m}-\theta_{m}^{i}\right)^{2}\right)\right]
\end{aligned}
$$

where $J c c=(\theta, P(j, k, l))$ is the fitness function be added to the actual fitness function, $S$ is the number of bacteria, $\mathrm{p}$ is the number of variables to be optimized. $\theta=\left[\begin{array}{llll}\theta 1 & \theta 2 & \ldots & \theta p\end{array}\right]^{T}$ represents a point in the $\mathrm{p}$ dimensional search field, $d_{\text {attract }}$ and $\omega_{\text {attract }}$ are the depth and breadth of the attractant released respectively, while $h_{\text {repellant }}$ and $\omega_{\text {repellant }}$ represents the height and width of the repellent respectively. The fitness of each position is determined using:

$J(i, j, k, l)=J(i, j, k, l)+J_{c c}(\theta, P(j, k, l))$

c. Reproduction: In this case, after $N c$ chemotaxis steps, the reproduction step is obtained by sorting the health of all bacteria based on fitness described by:

$$
J_{\text {health }}^{i}=\sum_{j}^{N_{c}+1} J(i, j, k, l)
$$

The Sr bacteria (the population of the bacteria divided into two equal halves) with least health due to insufficient nutrient eventually die leaving the healthiest to split into two similar bacteria and positioned at the same location.

d. Elimination and Dispersion: The process of elimination and dispersion is executed after Nre reproduction steps so as to avoid being stocked in local optima. Each bacterium is subjected to the process of dispersal and elimination within the environment according to a probability $(\mathrm{Ped}) . \mathrm{Nel}$ is the number of elimination and dispersal steps. Figure 3 shows a flow chart of the conventional BFA.

Figure 3 shows the flow chart of the classical bacterial foraging algorithm.

\subsection{Quadratic AdaPtive Bacterial FORAGING ALGORITHM}

The QABFA is also based on the four behaviours of the BFA. However, its runlength unit is made adaptive, based on the fitness function $J(i)$, and the cell-to-cell swarming mechanism is eliminated [21]. 


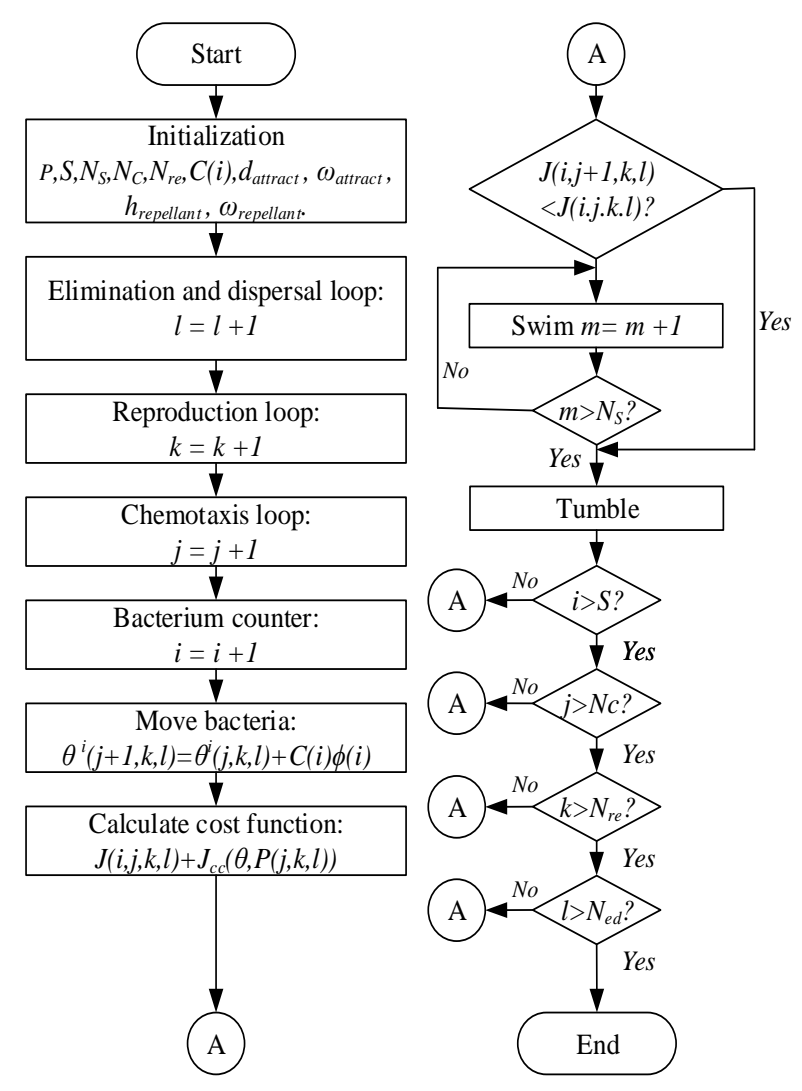

Fig. 3. Flow chart of conventional bacterial foraging algorithm

The QABFA run-length unit is thus expressed as:

$$
C_{q}(i)=\frac{c_{\max }}{1+\frac{\alpha}{\beta\left(|J(i)|^{2}+|J(i)|\right)}}
$$

where $C_{q}(i)$ represents the quadratic adaptive run-length for all bacterium, $c_{\max }$ is tuneable peak run-length unit, $|J(i)|$ is the absolute cost function of every bacterium, and $\alpha$ and $\beta$ are positive tuneable factor and scaling factor respectively. A complete pseudo-code of the QABFA is presented below and the flow chart is shown in Figure 4.

[Step 1] Initialize parameters:

$p, S, N_{S}, N_{c}, N_{r e}, N_{e d} P_{e d}, C(i), \theta^{i}(i=1,2, \ldots, S)$

[Step 2] Elimination and the dispersal loop:

$$
\text { for } l=l+1
$$

[Step 3] Reproduction loop:

$$
\text { for } k=k+1
$$

[Step 4] Chemotaxis loop:

$$
\begin{aligned}
& \text { for } j=j+1 \\
& \text { 4.1. for each bacterium } i=1,2, \ldots, S \text {, } \\
& \text { 4.2. determine the cost function } J(i, j, k, l) \\
& \text { 4.3. } J_{\text {last }}=J(i, j, k, l) \\
& \text { 4.4. Tumbling: Create a random vector } \\
& \text { set } \Delta(i) \in_{i}{ }^{p} \\
& \text { while } m<N_{S} \\
& m=m+1 \\
& \text { if } J(i, j+1, k, l)<J_{\text {last }} \text { then } \\
& J_{\text {last }}=J(i, j+1, k, l) \\
& \text { else } \\
& m=N_{S} \\
& \text { end } \\
& \text { end }
\end{aligned}
$$

[Step 5] if $j<N_{c}$, move to step 4

\section{[Step 6] Reproduction}

$$
\begin{aligned}
& \text { for } i=1,2, \ldots, S, \\
& \quad 6.1 \text { Compute } J_{\text {health }}^{i} \text { using equation (14) } \\
& \text { end }
\end{aligned}
$$

6.2 Sort bacteria in order of ascending. The smallest healthier bacteria $\left(S_{r}\right)$ die and others divided into two bacteria and placed in the same place.

end

[Step 7] if $k<N_{\text {re }}$ go to step 3

[Step 8] Elimination-dispersal:

for $m=1,2, \ldots, S$,

8.1 if $p_{e d}>$ rand (create a random number for each bacterium and if any number is lower than $p_{e d}$ then discard or destroy the bacterium) 
Create new random locations for the bacteria else

Bacteria remain in their place.

$$
\text { end }
$$

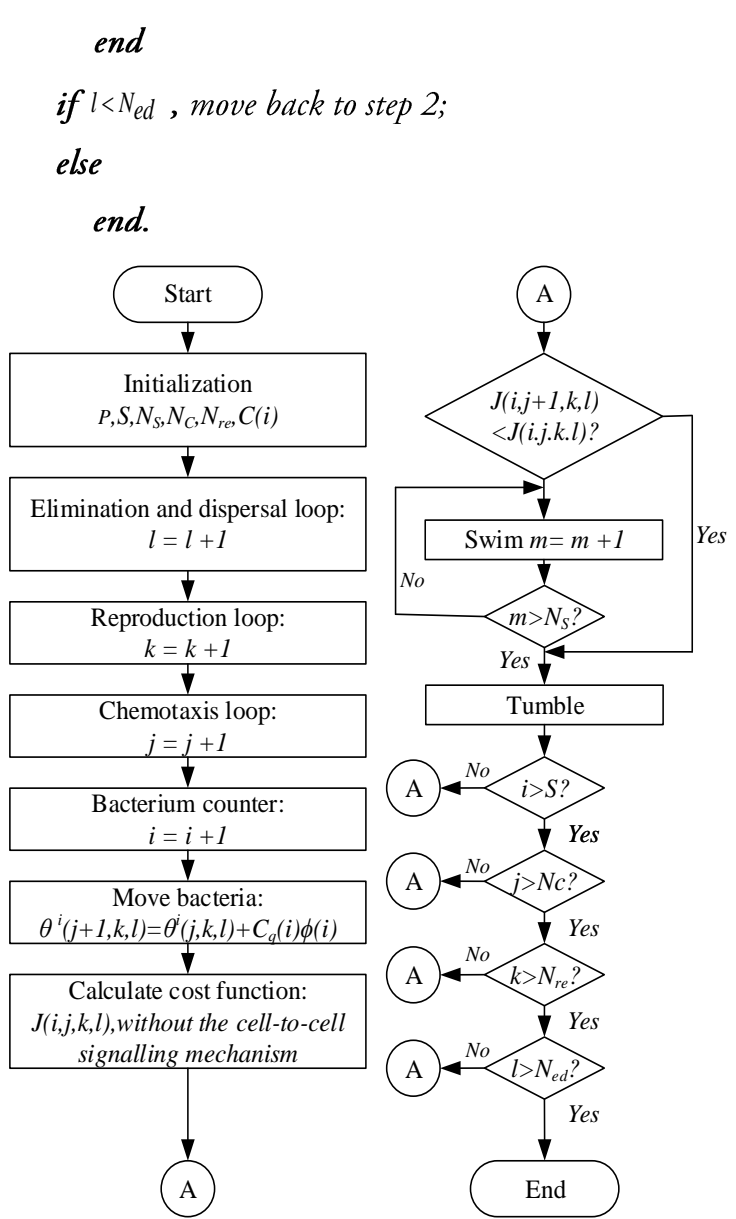

Fig. 4. Flow chart of quadratic adaptive bacterial foraging algorithm

\subsection{PROPOSED METHODOLOGY}

The analysis has been performed in MATLAB 2013a virtual platform in a personal computer with the following specifications:

a. Intel(R) Core(TM) 2Duo CPU P8700;

b. $2.53 \mathrm{GHz}$ 64-based processor;

c. 4GB installed memory (RAM); and

d. 32-bit windows 8 Operating System (OS).

A step by step approach for implementing the QABFA approach for optimal placement of D-STATCOM in the system is as shown in Figure 5.

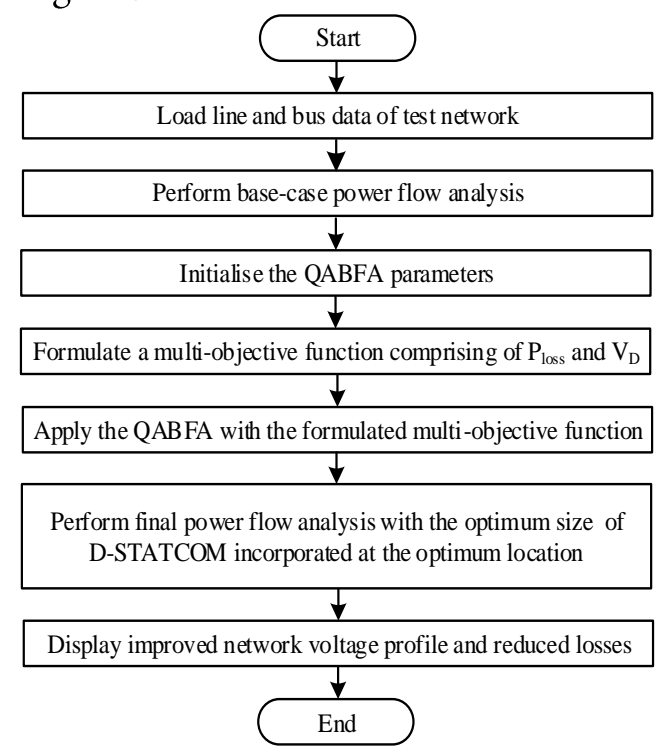

Fig.5. Flow chart of proposed QABFA algorithm.

Table 1 presents the parameters for both the BFA and QABFA used in this paper.

TABLE 1: PARAMETERS SETTING FOR THE PROPOSED QABFA

\begin{tabular}{|c|c|}
\hline Parameters & Values \\
\hline Search space dimensions, $p$ & 2 \\
\hline Size of the bacteria, $S$ & 10 \\
\hline Total chemotactic steps, $N_{c}$ & 4 \\
\hline Total swim steps, $N_{s}$ & 4 \\
\hline Total reproductive steps, $N_{r e}$ & 4 \\
\hline Total elimination and dispersal steps, $N_{e d}$ & 3 \\
\hline Run-length unit $C(i)$ & 0.1 \\
\hline $\begin{array}{l}\text { Total bacteria reproductions (splits) per } \\
\text { generation, } S_{r}\end{array}$ & $S / 2$ \\
\hline $\begin{array}{l}\text { Probability of elimination and dispersal of } \\
\text { bacteria, } P_{e d}\end{array}$ & 0.25 \\
\hline Gravity of attractant, $d_{\text {attract }}$ & 0.1 \\
\hline Breadth of attractant, $\omega_{\text {ttract }}$ & 0.2 \\
\hline Repellent height, $h_{\text {repellant }}$ & 0.1 \\
\hline Breadth of the repellent, $\omega_{\text {epellant }}$ & 10 \\
\hline Tuneable factor, $\alpha$ & 1 \\
\hline Scaling factor, $\beta$ & 0.01 \\
\hline
\end{tabular}




\section{RESULT AND DISCUSSIONS}

\subsection{A Standard IEEE 33-Bus Radial DISTRIBUTION NETWORK}

To examine the efficiency of the QABFA approach, the IEEE 33-bus radial distribution system data are adopted from [22]. Line voltage, base MVA, real and reactive loads of the network are given as $12.66 \mathrm{kV}, 100 \mathrm{MVA}, 3.72 \mathrm{MW}$ and 2.3MVAr respectively. It should be noted that the authors have selected the lower and upper bus voltage limits as $1.05 \mathrm{pu}$ and $0.95 \mathrm{pu}$ respectively, while the maximum limit of D-STATCOM is taken as $100 \%$ of the network total $\mathrm{kVAr}$ loading $(2300$ $\mathrm{kVAr}$ ). Table 2 shows comparison of the results with D STATCOM and the BA technique at the best location of the test network. The performance comparison for voltage profile is shown in Figures 6.
Despite the ability of both approaches to improve the bus voltage levels, it is clear that the proposed approach recorded better voltage magnitude than the BA method. Figure 7 depicts the active power loss across all branches. The installation of DSTATCOM at bus 29 has drastically reduced the network losses. It can be observed from Figure 7 that the highest bar at branch 2 with an approximate value of $51.57 \mathrm{~kW}$ has been reduced to $36.99 \mathrm{~kW}$ with the placement of D-STATCOM via QABFA. Similarly, the reactive power loss at each branch is shown in Figure 8. The highest bar at branch 5 which signifies the branch with the highest reactive power loss with a value of $26.27 \mathrm{kVAr}$, has been reduced to $18.18 \mathrm{kVAr}$ with the installation of D-STATCOM by the proposed approach.

TABLE 2: COMPARISON OF SIMULATION RESULTS OF THE IEEE 33-BUS RADIAL DISTRIBUTION NETWORK

\begin{tabular}{|c|c|c|c|}
\hline Items & Base-case & BA [3] & QABFA \\
\hline Optimum Location & - & $30^{\text {th }}$ bus & $29^{\text {th }}$ bus \\
\hline Optimum Size (kVAr) & - & 1150 & 1338 \\
\hline $\mathrm{V}_{\min }(\mathrm{p} . u)$ & $0.9134-$ bus 18 & $0.9244-$ bus 18 & $0.9282-$ bus 18 \\
\hline$\%$ Voltage profile improvement & - & 37.96 & 143.11 \\
\hline$P_{\text {loss }}(\mathrm{kW})$ & 201.89 & 143.97 & 28.96 \\
\hline$\%$ Reduction in Ploss & - & 28.69 & 96.28 \\
\hline Qloss $(\mathrm{kVAr})$ & 134.64 & 95.61 & 28.49 \\
\hline \% Reduction in Qloss & - & 28.99 & 12 \\
\hline No of buses out of constraint limits & 21 & 13 & \\
\hline
\end{tabular}




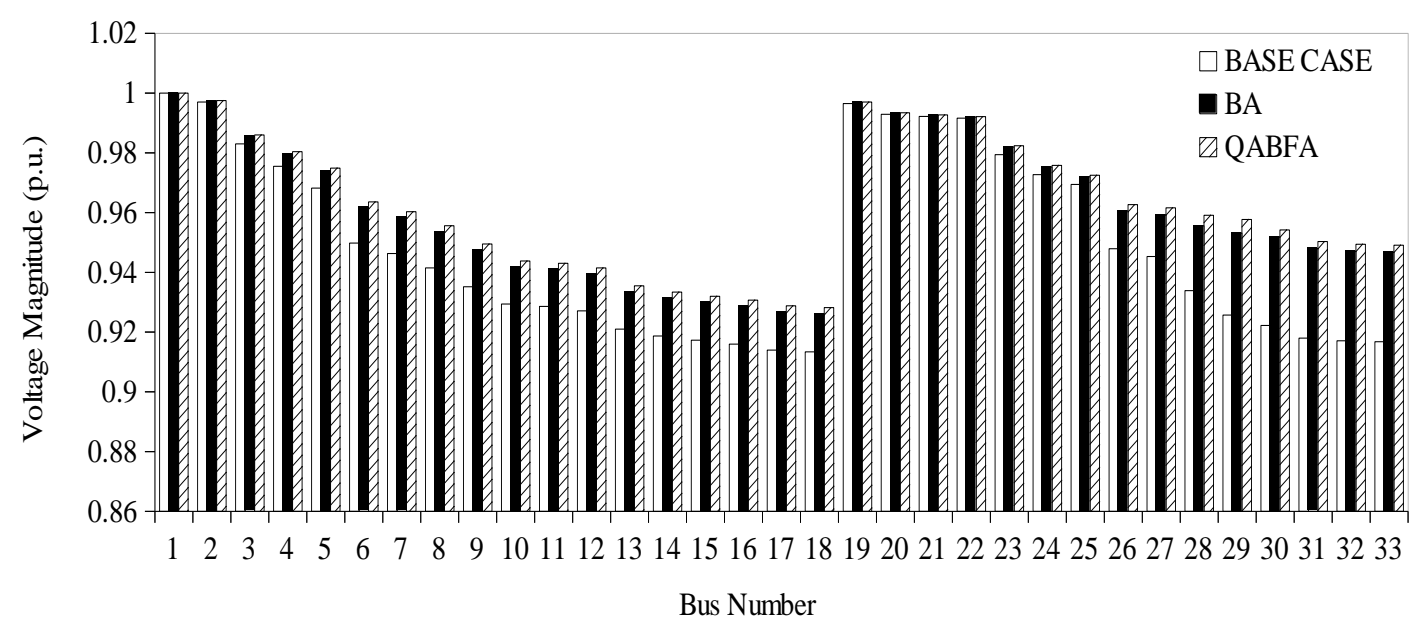

Fig. 6. Power loss of 33-bus radial distribution network with and without D-STATCOM.

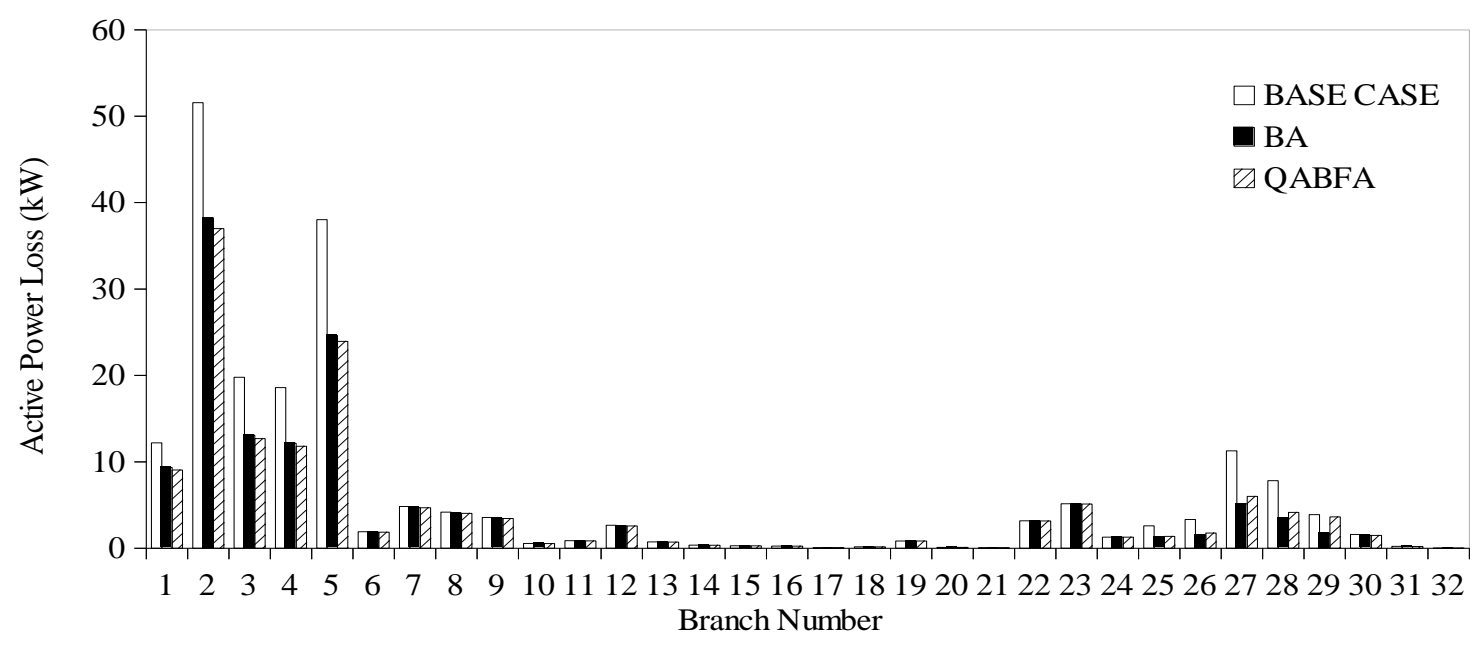

Fig. 7. Active power loss of 33-bus radial distribution network with and without D-STATCOM.

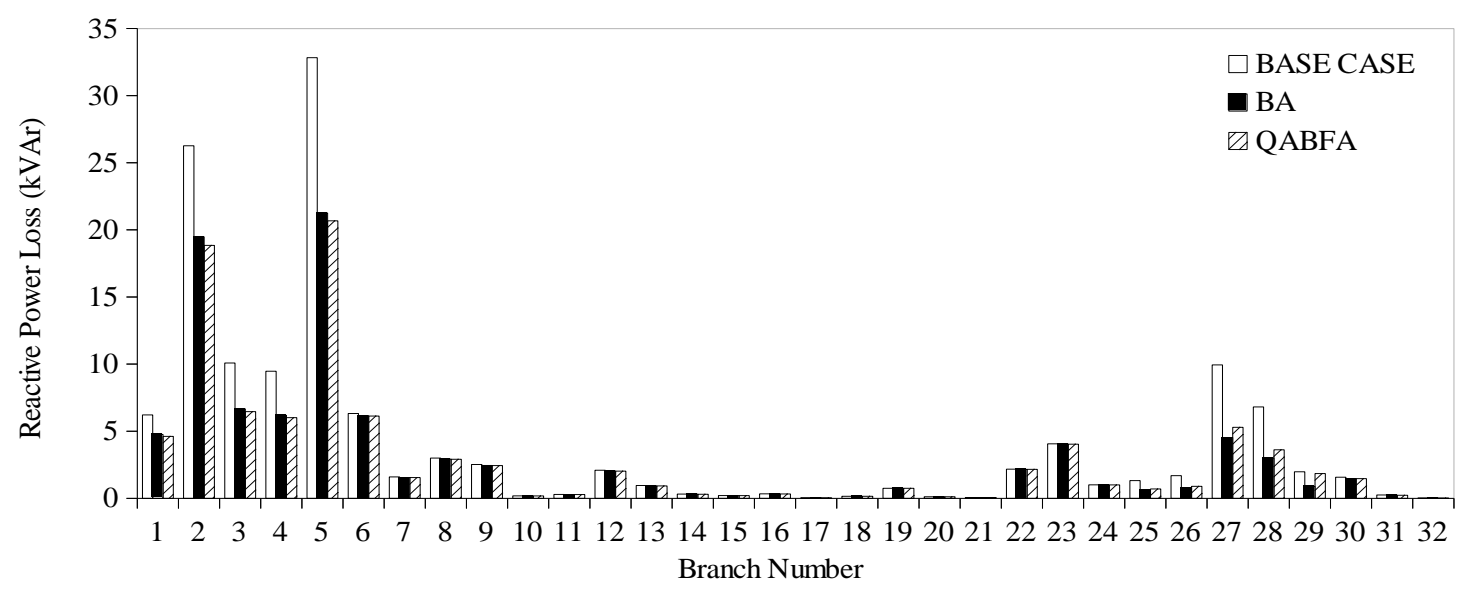

Fig. 8. Reactive power loss of 33-bus radial distribution network with and without D-STATCOM. 
Also, the placement of D-STATCOM using QABFA has reduced the number of buses out of constraint limits, as 10 out of the 21 buses in the base-case have been improved to within the specified voltage limits. From the results summaries presented in Table 2 and Figures 6 to 8 , it is obvious that the location and sizing of D-STATCOM by the proposed QABFA approach, has significantly enhanced the overall voltage profile and minimize the power losses associated with the network. Although the existing BA approach has managed to obtain the best size of D-STATCOM and a slight reduction in reactive power losses compared to QABFA in the network, the same cannot be said for the other items considered. From the number of items shown in Table 2, it is evident that the QABFA approach outperforms the BA approach.

\section{CONCLUSION}

A QABFA based approach has been applied to obtain the optimal placement of DSTATCOM in radial distribution network. A direct power flow method based on BIBC matrix was used in calculating power losses and bus voltage deviation. The performance of the proposed technique is tested on a standard IEEE 33-bus radial distribution system. The results obtained clearly show that the installation of D-STATCOM using the QABFA approach has successfully reduced losses and improved network voltage profile. In comparison to the basecase scenario, the QABFA signifies a $28.96 \%$ decrease in active power loss and $43.11 \%$ enhancement in the total network voltage profile. When compared to the existing BA approach, the QABFA results confirmed a slight reduction $(0.83 \%)$ in active power loss and $11.95 \%$ in voltage profile. Placement of D-STATCOM using the proposed approach considering network loadability will be considered in subsequent work.

\section{REFERENCES}

[1] Tchokonte, Y.N.N., Real-time identification and monitoring of the voltage stability margin in electric power transmission systems using synchronized phasor measurements. 2009, Kassel University press GmbH.

[2] Murty, P., Operation and control in power systems. 2008: BS Publications.

[3] Yuvaraj, T., K. Ravi, and K. Devabalaji, DSTATCOM allocation in distribution networks considering load variations using bat algorithm. Ain Shams Engineering Journal, 2015: p. 1-13.

[4] Singh, B., et al., Introduction to FACTS Controllers: A Technological Literature Survey. International Journal of Automation and Power Engineering, 2012. 1(9): p. 193-234.

[5] Gupta, A.R. and A. Kumar, Energy Savings Using D-STATCOM Placement in Radial Distribution System. Procedia Computer Science, 2015.70: p. 558-564.

[6] Yuvaraj, T., K. Devabalaji, and K. Ravi, Optimal placement and sizing of DSTATCOM using Harmony Search algorithm. Energy Procedia, 2015. 79: p. 759-765.

[7] Shanmugasundaram, P. and A.R. Babu. Application of DSTATCOM for Loss Minimization in Radial Distribution System. in Proceedings of the International Conference on Soft Computing Systems. 2016. Springer.

[8] Devabalaji, K., T. Yuvaraj, and K. Ravi, An efficient method for solving the optimal sitting and sizing problem of capacitor banks based on cuckoo search algorithm. Ain Shams Engineering Journal, 2016: p. 1-9.

[9] Devi, S. and M. Geethanjali, Application of modified bacterial foraging optimization algorithm for optimal placement and sizing of distributed generation. Expert Systems with Applications, 2014. 41(6): p. 2772-2781.

[10] Yuvaraj, T., K. Ravi, and K. Devabalaji, Optimal Allocation of DG and DSTATCOM in Radial Distribution System Using Cuckoo Search Optimization Algorithm. Modelling and Simulation in Engineering, 2017.

[11] Sedighizadeh, M. and A. Eisapour-Moarref, The Imperialist Competitive Algorithm for 
Optimal Multi-Objective Location and Sizing of DSTATCOM in Distribution Systems Considering Loads Uncertainty. INAE Letters, 2017. 2(3): p. 83-95.

[12] Sanam, J., et al., Optimization of Energy Loss Cost of Distribution Networks with the Optimal Placement and Sizing of DSTATCOM Using Differential Evolution Algorithm. Arabian Journal for Science and Engineering, 2017: p. 1-15.

[13] Sanam, J., S. Ganguly, and A. Panda, Distribution STATCOM with optimal phase angle injection model for reactive power compensation of radial distribution networks. International Journal of Numerical Modelling: Electronic Networks, Devices and Fields, 2017.

[14] Sanam, J., A. Panda, and S. Ganguly, Optimal phase angle injection for reactive power compensation of distribution systems with the allocation of multiple distribution STATCOM. Arabian Journal for Science and Engineering, 2017. 42(7): p. 2663-2671.

[15] Mohammadi, M., M. Abasi, and A.M. Rozbahani, Fuzzy-GA based algorithm for optimal placement and sizing of distribution static compensator (DSTATCOM) for loss reduction of distribution network considering reconfiguration. Journal of Central South University, 2017. 24(2): p. 245-258.

[16] Mokhtari, A., et al., Study, analysis and simulation of a static compensator DSTATCOM for distribution systems of electric power. Leonardo Journal of Sciences, 2014(25): p. 117-130.
[17] Hussain, S.S. and M. Subbaramiah. An analytical approach for optimal location of DSTATCOM in radial distribution system. in International Conference on Energy Efficient Technologies for Sustainability (ICEETS), 2013. . 2013. IEEE.

[18] Jain, A., A. Gupta, and A. Kumar. An efficient method for D-STATCOM placement in radial distribution system. in IEEE 6th India International Conference on Power Electronics (IICPE). 2014. IEEE.

[19] Passino, K.M., Bacterial foraging optimization. Innovations and Developments of Swarm Intelligence Applications, 2012: p. 219.

[20] Xing, B. and W.-J. Gao, Innovative computational intelligence: a rough guide to 134 clever algorithms. Vol. 62. 2014: Springer. 469.

[21] Supriyono, H. and M.O. Tokhi. Bacterial foraging algorithm with adaptable chemotactic step size. in Second International Conference on Computational Intelligence, Communication Systems and Networks (CICSyN), 2010. . 2010. IEEE.

[22] Taher, S.A. and S.A. Afsari, Optimal location and sizing of DSTATCOM in distribution systems by immune algorithm. International Journal of Electrical Power \& Energy Systems, 2014. 60: p. 34-44. 


\title{
الوضع الأمثل لاجهزة ستاتسوم-الموزعة باستخدام خوارزمية تكيف بكتيريا العلف التربيعية
}

\author{
عمر موسى'، غانيو باكر²، عبد اله ا. ماتي 1,3، عبد الله ابو بكر مسعود4 \\ 1 قسم الهنسة الكهربية والكومبيوتر، جامعة أحمدو بيللو، زاريا، نيجيريا. \\ 22 قسم الهنسة الكهريبة و الإلكترونية، جامعة عبدالقادر ثافاو باليوا، باوشي، نيجيريا. \\ 3 مركز تدريب وابحاث الطاقة، جامعة أحمدو بيللو، زاريا، نيجيريا. \\ 4 قسم الهندسة الكهربية والإلكترونية، كلية الجبيل الصناعية، مدينة الجبيل الصناعية، المملكة العربية السعودية.
}

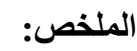

إن إختيار الوضع الأمثل لأنظمة التوزيع المرنة الموزعة في شبكات الطاقة يزيد من قابلية التحميل، ويعوض القدرة الغير فعالة، ويقلل من مفاقيد الطاقة ويعزز الجهد. في هذا البحث، تم استخدام خوارزمية تكيف بكتيريا العلف التربيعية للحصول علي المكان والحجم الأمثلين من الموزع الساكن (D-ستاتسوم) في شبكات التوزيع لتقليل مفاقيد الطاقة وتعزيز الجهر. تم حساب مفاقيد الطاقة وانحراف الجهد باستخدام طريقة تدفق الطاقة المباثرة. وتم صياغة دالة متعددة الأهدف وهي عبارة عن مجموع مفاقيد الطاقة الفعالة والتغير في الجهد. نم تصميم نموذج تكيف بكتيريا العلف ذات طول تربيعي، وبدون آلية التشوير من خلية إلى خلية. وتم التحقيق في فعالية الطريقة المقترحة على الثبكة القياسية IEEE 33-bus. وأسفر النهج الدقترح عن انخفاض بنسبة 28.96٪ في إجمالي خسارة الطاقة الفعالة و تحسن بنسبة 43.11٪ في إجمالي الجهد الكهربائي للشبكة مقارنة بسيناريو الحالة الأساسية. وبالمثل، بالمقارنة مع نهج خوارزمية الخفافيش (با)، أكدت النتائج المقترحة انخفاضا طفيفا (0.83\%) في فقدان الطاقة الفعالة وتحسن 11.95\% في الجهود. 